\title{
The Type and Source of Reactive Oxygen Species Influences the Outcome of Oxidative Stress in Cultured Cells
}

\author{
Steffi Goffart ${ }^{1,+} \mathbb{D}$, Petra Tikkanen ${ }^{1,+}$, Craig Michell ${ }^{1} \mathbb{D}$, Trevor Wilson ${ }^{2}$ and Jaakko L. O. Pohjoismäki ${ }^{1, *(\mathbb{D})}$ \\ 1 Department of Environmental and Biological Sciences, University of Eastern Finland, \\ FI-80101 Joensuu, Finland; Steffi.Goffart@uef.fi (S.G.); pertsa_tikkanen@hotmail.com (P.T.); \\ craig.michell@uef.fi (C.M.) \\ 2 Medical Genomics Facility, Monash Medical Centre, Hudson Institute of Medical Research, \\ Clayton, VIC 3168, Australia; trevor.wilson@hudson.org.au \\ * Correspondence: Jaakko.Pohjoismaki@uef.fi; Tel.: +358-505-744-745 \\ $\dagger$ These authors contributed equally to this paper.
}

Citation: Goffart, S.; Tikkanen, P.; Michell, C.; Wilson, T.; Pohjoismäki, J.L.O. The Type and Source of Reactive Oxygen Species Influences the Outcome of Oxidative Stress in Cultured Cells. Cells 2021, 10, 1075. https://doi.org/10.3390/cells10051075

Academic Editor: Bartosz Szczesny

Received: 15 March 2021

Accepted: 28 April 2021

Published: 30 April 2021

Publisher's Note: MDPI stays neutral with regard to jurisdictional claims in published maps and institutional affiliations.

Copyright: (c) 2021 by the authors. Licensee MDPI, Basel, Switzerland. This article is an open access article distributed under the terms and conditions of the Creative Commons Attribution (CC BY) license (https:/ / creativecommons.org/licenses/by/ $4.0 /)$.

\begin{abstract}
Oxidative stress can be modeled using various different experimental approaches, such as exposing the cells or organisms to oxidative chemicals. However, the actual effects of these chemicals, outside of the immediate measured effect, have attracted relatively little attention. We show here that three commonly used oxidants, menadione, potassium bromate, and hydrogen peroxide, while known to function differently, also elicit different types of responses in HEK293T cells. Menadione and bromate exposure mainly trigger an integrated stress response, whereas hydrogen peroxide affects cellular processes more diversely. Interestingly, acute oxidative stress does not universally cause notable induction of DNA repair or antioxidant defense mechanisms. We also provide evidence that cells with previous experience of oxidative stress show adaptive changes in their responses when the stress is renewed. Our results urge caution when comparing studies where different sources of oxidative stress have been used or when generalizing the findings of these studies to other oxidant types or tissues.
\end{abstract}

Keywords: oxidative stress; DNA damage; mitochondria; unfolded protein response (UPR); integrated stress response; ATF4; bromate; menadione; hydrogen peroxide; RNA sequencing

\section{Introduction}

Electron-deficient atoms or molecules, having unpaired valence electrons, can draw electrons from others, making them chemically highly reactive [1]. Consequently, these species are commonly known as free radicals, causing significant harm to biological macromolecules such as proteins, lipids, and nucleic acids [2]. Considering the abundance and chemical nature of oxygen, reactive oxygen species (ROS) are the most important naturally occurring type of free radicals. It should also be noted that not all ROS, such as peroxides, are radicals. In cells, the main source of ROS is the mitochondrial electron transport chain, where uncontrolled leakage of electrons through complexes I and III can generate superoxide $\left(\mathrm{O}_{2}{ }^{-}\right)$from oxygen [3]. Superoxide is then either spontaneously dismutated or actively converted to hydrogen peroxide $\left(\mathrm{H}_{2} \mathrm{O}_{2}\right)$ by the mitochondrial superoxide dismutase (SOD2) and further to water $\left(\mathrm{H}_{2} \mathrm{O}\right)$ by catalase, peroxiredoxins ( $\mathrm{PRXs}$ ), or glutathione peroxidases (GSHs). Although $\mathrm{O}_{2}{ }^{-}$and $\mathrm{H}_{2} \mathrm{O}_{2}$ are not especially reactive themselves, their reactions with transition metals generate extremely reactive hydroxyl radicals $(\mathrm{OH} \cdot)$, which cause the majority of oxidative damage in cells [4].

The effects of ROS on cells have been studied intensively because of their importance in human pathologies, cellular signaling, and ageing $[2,3,5]$. While oxidative stress can be experimentally increased by genetic manipulation of antioxidant defenses [6] or ionizing radiation [7], the most common method is to expose cells or animals to chemicals that cause oxidative stress. These compounds can be oxidants themselves, block the mitochondrial 
electron transport chain (ETC), or bypass respiratory complexes by transferring electrons directly to oxygen. An example of the latter is menadione, a quinone and vitamin $\mathrm{K}$ analogue, which can transfer electrons from the ETC complex I directly to oxygen, generating superoxide [8]. Menadione has been used for a long time in a broad spectrum of studies to induce oxidative stress, cell damage, and cell death [9-12]. Similarly, $\mathrm{H}_{2} \mathrm{O}_{2}$ has offered an easy experimental source of ROS stress and is widely used in experimentation [13]. However, $\mathrm{H}_{2} \mathrm{O}_{2}$ is notoriously difficult to handle reproducibly, has a relatively short halflife, and is prone to both enzymatic and chemical elimination in culture medium or in cells $[13,14]$. Generally, the $\mathrm{H}_{2} \mathrm{O}_{2}$ quantities required to induce oxidative damage are an order of magnitude higher than for other ROS stressors.

Our group has been interested in the consequences of oxidative damage on mtDNA, which we have modeled mainly by exposing cells to potassium bromate $\left(\mathrm{KBrO}_{3}\right)$ [15-17]. In contrast to menadione, bromate can directly oxidize macromolecules, including DNA, in cells $[16,18]$. In mitochondria, potassium bromate treatment increases the levels of 8-oxoguanine (8-oxoG) modifications on mtDNA [16] and causes persistent changes in its replication mechanisms $[15,16]$. However, it can be argued that menadione-induced oxidative stress is physiologically more relevant than oxidative stress induced by potassium bromate, as it is supposed to catalyze superoxide formation from the electron transport chain and simulate the natural source of ROS during intense oxidative metabolism [3]. However, this is not the entire picture. In fact, a number of studies have shown that menadione can have notable systemic effects in cells, assumably by inducing the formation of ROS at multiple cellular compartments [11,19].

In order to understand the differences between oxidative stressors and evaluate their relevance for modelling various physiological sources of ROS damage, we have compared the effects of menadione, potassium bromate, and $\mathrm{H}_{2} \mathrm{O}_{2}$ on different cellular stress responses. While menadione elicits intrinsic ROS by producing $\mathrm{O}_{2}{ }^{-}$within the mitochondria, the effects of $\mathrm{KBrO}_{3}$ and $\mathrm{H}_{2} \mathrm{O}_{2}$ can cause direct oxidative damage at the cell surface or upon entry into the cells. While superoxide and $\mathrm{H}_{2} \mathrm{O}_{2}$ can convert to highly reactive hydroxyl radicals via Fenton and Haber-Weiss reactions [3], $\mathrm{H}_{2} \mathrm{O}_{2}$ can also directly oxidize thiolate groups on proteins, which is also an important part of the signaling function of the compound [20]. As the superoxide resulting from menadione treatment can be converted to $\mathrm{H}_{2} \mathrm{O}_{2}$, one would also expect the two oxidants to have comparable effects on cells.

In the presented study, we have interrogated oxidative stress signaling pathways, DNA damage responses, and changes in the global gene expression patterns in cells treated with menadione, $\mathrm{KBrO}_{3}$, and $\mathrm{H}_{2} \mathrm{O}_{2}$, and show them to cause rather dissimilar effects on cells. Our study emphasizes the notion that not all ROS stressors are equal, and that caution should be exercised when generalizing the findings from different studies.

\section{Materials and Methods}

\subsection{Cell Culture and Induction of Oxidative Stress}

Human HEK293T cells were cultured in low glucose Dulbecco's Modified Eagle Medium (DMEM, BioWest, Nuaille, France; L0103-500) with 10\% fetal bovine serum (FBS) and $1 \%$ penicillin/streptomycin. Cells were incubated at $37^{\circ} \mathrm{C}$ and $100 \%$ humidity with $8.5 \% \mathrm{CO}_{2}$. To induce oxidative stress, cells were treated at $80 \%$ confluency with menadione, $\mathrm{H}_{2} \mathrm{O}_{2}$, or $\mathrm{KBrO}_{3}$ using the concentrations and times given in the results. In experiments where a recovery phase was included, DMEM with the oxidizing agent was gently removed and replaced with fresh DMEM for up to $48 \mathrm{~h}$. As the cells would have grown confluent in the retreatment experiments, they were split 1:3 in fresh medium after the first treatment.

For growth curve experiments, $10^{5}$ cells were seeded into 6-well plates and grown for $24 \mathrm{~h}$ before addition of the oxidizing agents. At 0 and $24 \mathrm{~h}$, cells were detached with trypsin/EDTA and counted using a Luna-FL cell counter (Logos Biosystems, Gyeonggi-do, Korea) with four biological replicates. 


\section{2. roGFP Constructs and Measurements}

The genes encoding cytosolic and mitochondrial matrix-targeted roGFP [21], a redoxsensitive probe, based on modified GFP, were recloned from Addgene vectors 49,435 and 49,437 into pcDNA5FRT /TO and transfected into Flp-In T-REx 293 cells (Thermo Fisher Scientific, Waltham, MA, USA) to create stable cell lines with tet-inducible expression. The cytosolic roGFP corresponds the native roGFP protein, whereas the mitochondrial version is a recombinant protein with a mitochondrial targeting sequence from cytochrome oxidase subunit IV at the $\mathrm{N}$-terminus (see [21] for details). These cells were grown in low glucose DMEM with $10 \%$ FBS, $100 \mu \mathrm{g} / \mathrm{mL}$ hygromycin and $10 \mu \mathrm{g} / \mathrm{mL}$ blasticidin on $6 \mathrm{~cm}$ plates and roGFP expression was induced for $48 \mathrm{~h}$ with $1 \mathrm{nM}$ doxycycline before the addition of $100 \mu \mathrm{M} \mathrm{H}_{2} \mathrm{O}_{2}, 10 \mu \mathrm{M}$ menadione or $30 \mu \mathrm{M} \mathrm{KBrO} 3$. After $4 \mathrm{~h}$ the medium was removed, the cells were detached with $1 \mathrm{~mL}$ PBS and $4 \times 200 \mu \mathrm{L}$ were transferred to a black 96-well plate with clear bottom. GFP fluorescence was measured in a FluoStar Omega plate reader (BMG Labtech), using excitation wavelengths of $405 \mathrm{~nm}$ and $480 \mathrm{~nm}$ and an emission wavelength of $>530 \mathrm{~nm}$. Each treatment was measured in two biological replicates; non-induced cells served as blank, and induced, untreated cells as control. To verify the presence of equal cell numbers in the different conditions, the protein concentration of each well was determined by Bradford assay and a variability of $<10 \%$ was found.

\subsection{MitoSOX Measurements}

Superoxide was quantified from live HEK293T cells using the fluorescent dye MitoSOX (Thermo Fisher Scientific). First, $5 \mathrm{mM}$ MitoSOX stock solution was prepared by dissolving one vial of MitoSOX (50 $\mu \mathrm{g})$ in $13 \mu \mathrm{L}$ DMSO. This stock then was diluted further with $130 \mu \mathrm{L}$ PBS. Cells treated with various oxidizing agents were washed with PBS, and $500 \mu \mathrm{L}$ fresh medium with $5 \mu \mathrm{L}$ MitoSOX was added, after which the cells were incubated $15 \mathrm{~min}$ at RT in the dark. Because HEK293T usually detached upon removal of DMEM/MitoSOX and washing with PBS, they could not be reliably measured on plates. Instead, the cells were completely resuspended in the MitoSOX-containing medium, quickly spun down by centrifugation and resuspended in $200 \mu \mathrm{L}$ PBS and the measurements were then made with this cell suspension. Fluorescence (absorption $400 \mathrm{~nm} /$ emission $590 \mathrm{~nm}$ ) was detected using a FLUOstar Omega microplate reader. To adjust for possible differences in cell density, the protein concentration of the resuspended samples was measured by Bradford assay and used as a normalization factor.

\subsection{Protein Extraction and Western Blot Analysis}

Cells resuspended in $1 \times$ PBS were spun down at $1000 \times g$ at $4{ }^{\circ} \mathrm{C}$ for $3 \mathrm{~min}$. The PBS was removed, and the cell pellet was lysed in $4 \times$ pellet volume of TotEx buffer $(20 \mathrm{mM}$ HEPES pH 7.9, $400 \mathrm{mM} \mathrm{NaCl}, 20 \%$ glycerol, 1\% IGEPAL, $1 \mathrm{mM} \mathrm{MgCl} 2,0.5 \mathrm{mM}$ EDTA, $0.1 \mathrm{mM}$ EGTA, $10 \mathrm{mM} \beta$-Glycerophosphate, $10 \mathrm{mM} \mathrm{NaF}, 9 \mathrm{mM}$ DTT, and $1 \times$ complete EDTA-free protease inhibitor cocktail). Next, 25-100 $\mu \mathrm{g}$ of the lysate was prepared for SDS-PAGE by mixing them with $1 / 4$ volume $5 \times$ Laemmli loading dye $(250 \mathrm{mM}$ Tris $\mathrm{pH} 6.8$, $10 \%$ SDS, 30\% glycerol, 0.5 M DTT, $0.02 \%$ bromophenol blue). Samples were denatured at $95{ }^{\circ} \mathrm{C}$ for $5 \mathrm{~min}$ and separated over 12 or $15 \%$ Laemmli gels at $100 \mathrm{~V}$ for $90 \mathrm{~min}$. The proteins were Western blotted onto nitrocellulose membrane in Towbin buffer $(25 \mathrm{mM}$ Tris, $200 \mathrm{mM}$ glycine, $0.1 \% \mathrm{SDS}, 20 \%$ methanol) at $100 \mathrm{~V}$ for $90 \mathrm{~min}$. The antibodies used in the study were as follows: anti-VDAC (Sigma Aldrich, St. Louis, MO, USA, \#SAB5201374), a mitochondrial outer-membrane protein used as a loading control; anti-vinculin (Sigma Aldrich, \#V9264), cytoskeletal protein used as a loading control; anti-ATF4 (Cell Signaling Technology, Danvers, MA, USA, \#11815), a transcription factor activated by integrated stress response; anti-phospho-eIF2 $\alpha$ (Ser51, Cell Signaling technology, \#3398), a translation factor phosphorylated upon unfolded protein response; and anti- $\gamma \mathrm{H} 2 \mathrm{AX}$ (Biovision, Milpitas, CA, USA, \#3761), a marker for nuclear DNA double-strand breaks. 


\subsection{PERK Inhibition}

Protein kinase R-like endoplasmic reticulum kinase or PERK is one of the main transducers of endoplasmic reticulum (ER) stress, whose participation in ROS stress was tested using $400 \mathrm{nM}$ of its specific inhibitor, GSK2606414 (Merck Millipore, Burlington, MA, USA). The used concentration is at the extreme high end of the tested concentrations for PERK inhibition [22], as we did not observe effects on eIF2 $\alpha$ phosphorylation in HEK293T cells using lower concentrations of the inhibitor. For all the experiments, the inhibitor was added into the medium $4 \mathrm{~h}$ prior to the addition of the oxidative agent or UV exposure. The control UV exposure was performed as previously [16].

\section{6. mtDNA Extraction and Two-Dimensional Agarose Gel Electrophoresis (2D-AGE)}

HEK293T cells were cultured in five $15 \mathrm{~cm}$ plates per condition. Cells were detached with the medium and concentrated to $15 \mathrm{~mL}$ DMEM. Then, $20 \mu \mathrm{g} / \mathrm{mL}$ of cytochalasin was added, and the cells were transferred to the incubator in a culture plate for $30 \mathrm{~min}$ incubation. The cells were transferred to a falcon tube and pelleted by centrifugation at $400 \times g$ and $4{ }^{\circ} \mathrm{C}$ for $5 \mathrm{~min}$. The pellet was resuspended in $5 \mathrm{~mL} \mathrm{H}$-buffer ( $225 \mathrm{mM}$ mannitol; $75 \mathrm{mM}$ sucrose; $10 \mathrm{mM}$ EDTA; $10 \mathrm{mM}$ HEPES-KOH pH 7,8; $1 \mathrm{mM}$ DTT; $1 \mathrm{mg} / \mathrm{mL}$ BSA) and cells were broken with 15 strokes in a tight Dounce homogenizer. To remove nuclei and unbroken cells, the samples were centrifuged at $800 \times g$ and $4{ }^{\circ} \mathrm{C}$ for $5 \mathrm{~min}$, after which the centrifugation was repeated with the supernatant. Again, the supernatant was transferred, and mitochondria pelleted by centrifugation at $12,000 \times \mathrm{g}$ and $4^{\circ} \mathrm{C}$ for $10 \mathrm{~min}$. The pellet was resuspended in $1 \mathrm{~mL} \mathrm{H}$-buffer with BSA and DTT and the mitochondria purified using ultracentrifugation and two-step sucrose gradient (1/1.5 M sucrose on $20 \mathrm{mM}$ HEPES $\mathrm{pH}$ 7.4 and $10 \mathrm{mM}$ EDTA). The mitochondria were lysed in $1 \mathrm{~mL}$ mitochondrial lysis buffer (20 mM HEPES pH 7.4, 1\% SDS, $150 \mathrm{mM} \mathrm{NaCl}, 10 \mathrm{mM}$ EDTA, $100 \mu \mathrm{g} / \mathrm{mL}$ proteinase $\mathrm{K}$ ) for $20 \mathrm{~min}$ on ice. The lysate was then extracted with phenol-chloroform as described above, the DNA precipitated with $1 \mathrm{vol}$ isopropanol and $20 \mu \mathrm{L} 5 \mathrm{M} \mathrm{NaCl}$ and the air-dried pellet was dissolved in $60 \mu \mathrm{L} 20 \mathrm{mM}$ HEPES pH 7.2.

For 2D-AGE (two-dimensional agarose gel electrophoresis), $5 \mu \mathrm{g}$ mtDNA were digested with $3 \mu \mathrm{L}$ DraI Fastdigest restriction enzyme (Thermo Scientific, Waltham, MA, USA) at $37^{\circ} \mathrm{C}$ for $3 \mathrm{~h}$ and extracted with 1 volume phenol-chloroform. The digested DNA was separated over a $0.4 \%$ agarose gel in TBE at $55 \mathrm{~V}$ overnight. To enable proper trimming for the second dimension, the $1 \mathrm{D}$ gel was stained with $1 \mu \mathrm{g} / \mathrm{mL}$ ethidium bromide in TBE and viewed under UV-light, so that the restriction fragments were visible. A $0.95 \%$ agarose second dimension in $1 \times$ TBE with $1 \mu \mathrm{g} / \mathrm{mL}$ ethidium bromide was cast around the cut $1 \mathrm{D}$ gel slices and separated overnight at $110 \mathrm{~V}$ with recirculation of TBE $+1 \mu \mathrm{g} / \mathrm{mL}$ ethidium bromide at $4{ }^{\circ} \mathrm{C}$. After the run, the gel was inspected with UV light to confirm the success of agarose gel electrophoresis and blotted using standard procedures. The DNA fragment of interest was detected by prehybridizing the blot in Church's buffer $(0.25 \mathrm{M}$ $\mathrm{Na} 2 \mathrm{HPO} 4 \mathrm{pH} 7.4,7 \% \mathrm{SDS}$ ) at $65^{\circ} \mathrm{C}$ for $>30 \mathrm{~min}$, hybridized with a ${ }^{32} \mathrm{P}$-labelled human ND6 (nucleotides 14374-14595 of mtDNA) probe in Church's buffer at $65^{\circ} \mathrm{C}$ overnight and washed for $3 \times 15 \mathrm{~min}$ in $1 \times$ SSC and $0.1 \%$ SDS. The radioactive signal was quantified with a Molecular Imager FX (BioRad) and Quantity One 4.6.2 software.

\subsection{RNA Extraction, Sequencing and Transcriptome Analysis}

To study the effects of the different oxidants on the transcriptional regulation of the HEK293T cells, the cells were exposed either to $10 \mu \mathrm{M}$ menadione, $30 \mu \mathrm{M}$ potassium bromate or $100 \mu \mathrm{M}$ hydrogen peroxide for $24 \mathrm{~h}$. For recovery experiments the cells were exposed to $30 \mu \mathrm{M}$ potassium bromate for $24 \mathrm{~h}$, after which the medium was removed, cells washed once with fresh medium and left to incubate in refreshed medium for another $24 \mathrm{~h}$. For retreatment, the cells were split 1:3 after the first $24 \mathrm{~h}$ exposure to $30 \mu \mathrm{M} \mathrm{KBrO}_{3}$, left to recover in fresh medium for $24 \mathrm{~h}$ and treated again with $30 \mu \mathrm{M} \mathrm{KBrO}$ for another $24 \mathrm{~h}$. All treatments were performed in three replicates, including controls. 
RNA was extracted from HEK293T using TRIzol (Thermo Fisher Scientific), following the manufacturer's instructions. RNA quality was assessed using the Agilent Bioanalyser, quantitated by Qubit (Thermo Fisher Scientific) and high-quality samples selected for analysis. RNA-Seq libraries were prepared using a multiplex $3^{\prime}$-capture method [23]. Briefly, $10 \mathrm{ng}$ of total RNA from each sample was tagged with an 8-base sample index and a 10-base unique molecular identifier (UMI) during initial poly(A) priming and reverse transcription. Samples were then pooled and amplified using a template switching oligonucleotide. The Illumina P5 (5'-AAT GAT ACG GCG ACC GA-3') and P7 (5'-CAA GCA GAA GAC GGC ATA CGA GAT-3') sequences were added by PCR and Nextera transposase, respectively. The library was designed so that the forward read (R1) utilized a custom primer ( $5^{\prime}$-GCC TGT CCG CGG AAG CAG TGG TAT CAA CGC AGA GTA C-3') to sequence directly into the index and then the 10 base UMI. The reverse read (R2) used the standard Illumina R2 primer to sequence the cDNA in the sense direction for transcript identification. Sequencing was performed on the NextSeq550 (Illumina), using the V2.5 high output kit generating two paired reads per cluster (19 bp, R1; $72 \mathrm{bp}, \mathrm{R} 2)$. Adapters, primers, and low-quality bases were removed from the ends of raw reads using Trimmomatic v.0.34 [24]. The resulting trimmed reads were mapped to the human genome (GRCh38) using STAR v.2.7.2 [25] and the count table was created with the "- quantMode GeneCounts" option. The differential expression was performed using the gene count table in DESeq2 [26]. Gene Ontology (GO) term enrichment analysis was performed using GOrilla [27] and DAVID Bioinformatics Resources 6.8 [28] online tools. The normalized transcriptome results are given in the Supplementary Material (Table S1).

\section{Results}

In order to get a first impression on how menadione, $\mathrm{KBrO}_{3}$, and $\mathrm{H}_{2} \mathrm{O}_{2}$ might differ in their action as ROS stressors, we compared the ability of these compounds to influence the oxidation of mitochondrial and cytoplasmic redox-sensitive molecular probes. Interestingly, high concentrations of $\mathrm{H}_{2} \mathrm{O}_{2}$ had little effect on cytoplasmic or mitochondrial ROS, whereas menadione induced roGFP oxidation in both compartments (Figure 1a). Somewhat unexpectedly, $\mathrm{KBrO}_{3}$-induced roGFP oxidation was specific for the mitochondrial compartment. A commonly used marker of mitochondrial oxidative stress, MitoSOX, reacted only with menadione (Figure 1b). This might not be surprising as MitoSOX is relatively specific for superoxide [29], which is generated by menadione but not by the other two chemicals.

Despite the differences in the observed oxidative stress, the highest concentrations of all drugs were able to stop cell proliferation (Figure 1c). Of note, menadione concentrations above $50 \mu \mathrm{M}$ and $\mathrm{H}_{2} \mathrm{O}_{2}$ concentrations above $200 \mu \mathrm{M}$ killed the HEK293T cells effectively, whereas $\mathrm{KBrO}_{3}$ was well-tolerated at the observed time points. While menadione-induced nuclear DNA double-strand break signaling was activated at relatively low concentrations (Figure 1d), this was not observed even with highest concentrations of $\mathrm{KBrO}_{3}$ and $\mathrm{H}_{2} \mathrm{O}_{2}$.

Next, we focused on the activation of integrated stress response (ISR) upon ROS stress. There are a number of different entries into ISR, but its key downstream signaling protein is ATF4, whose translation is increased upon ISR activation [30]. While ATF4 was substantially upregulated after $12 \mathrm{~h}$ of menadione exposure, $\mathrm{KBrO}_{3}$ and $\mathrm{H}_{2} \mathrm{O}_{2}$ again showed little or no effect (Figure 2a). However, when we studied the timing of ISR activation in more detail, we noted that $\mathrm{KBrO}_{3}$ caused an increase in ATF4 after more than $12 \mathrm{~h}$, while $\mathrm{H}_{2} \mathrm{O}_{2}$ only caused a transient increase in ATF4 levels at $4 \mathrm{~h}$ (Figure 2b). 
(a)

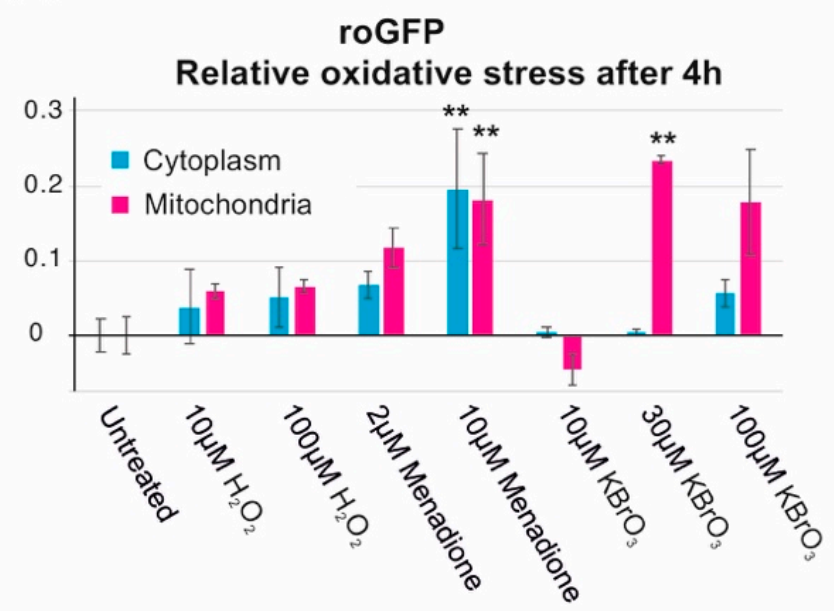

(c) Cell proliferation after $24 \mathrm{~h}$ (fold increase)
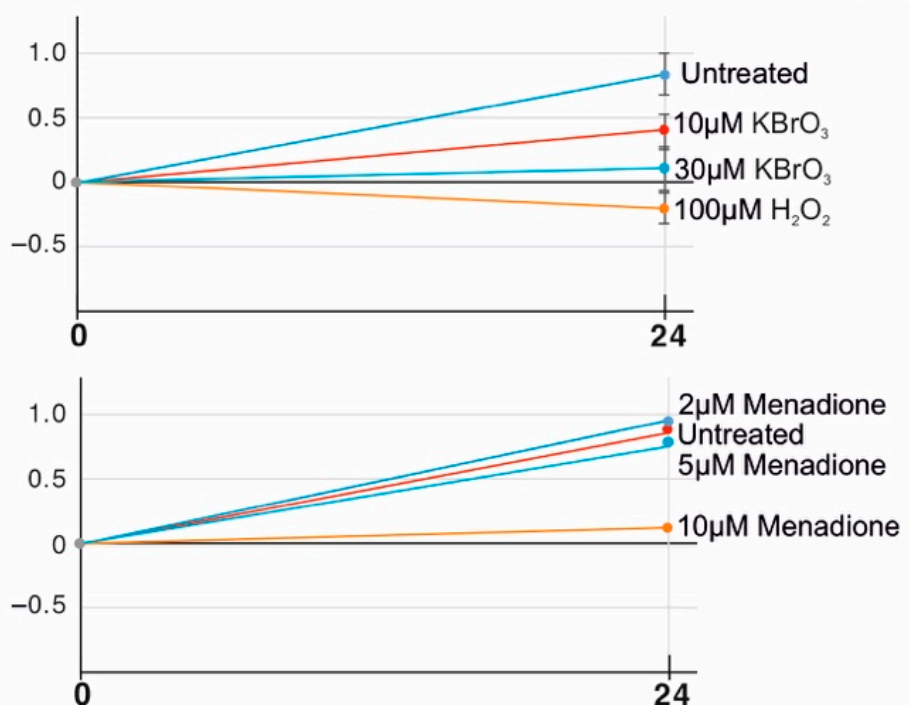

(b)

\section{Mitosox \\ Relative oxidative stress after $4 \mathrm{~h}$}
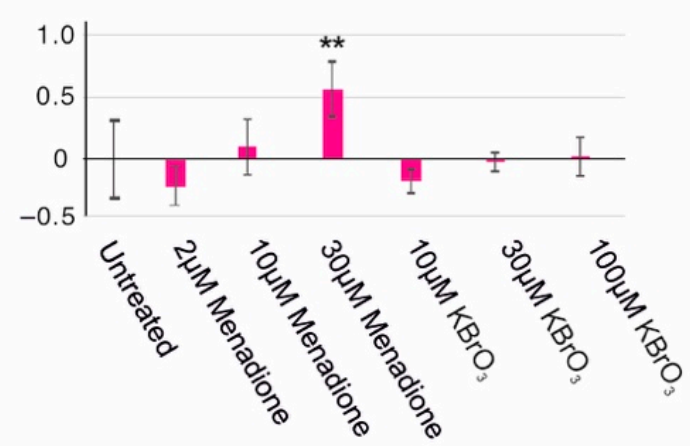

(d)
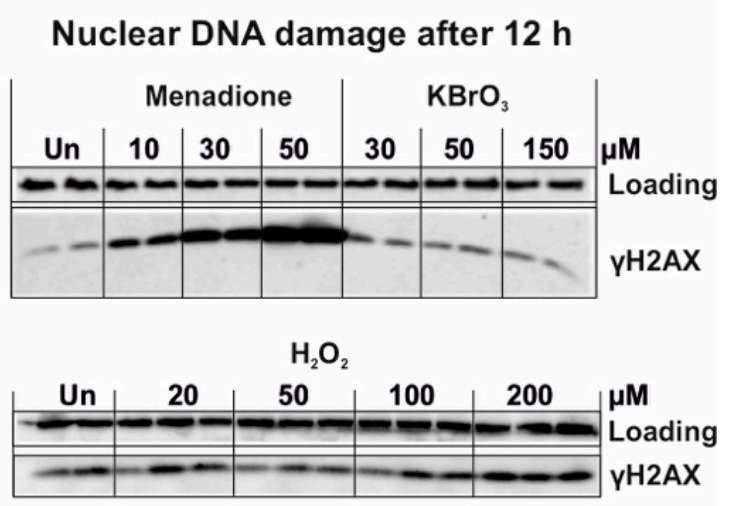

Figure 1. Oxidative stress, nuclear DNA damage, and cell proliferation after menadione, $\mathrm{KBrO}_{3}$, and $\mathrm{H}_{2} \mathrm{O}_{2}$ exposure. (a) Cytoplasmic and mitochondrial oxidative stress in HEK293T cells measured as a relative change in the roGFP fluorescence intensity after $4 \mathrm{~h}$ treatment with different oxidant concentrations. Measurements normalized against the untreated samples (0-fold change). (b) Mitochondrial superoxide levels in HEK293T cells after $4 \mathrm{~h}$ treatment with different oxidant concentrations. Measurements normalized against the untreated samples. (c) Cell proliferation measured as fold increase in cell number during $24 \mathrm{~h}$ exposure to different oxidant concentrations. Only selected concentrations shown to demonstrate the effective range of the chemicals. (d) Activation of nuclear DNA damage signaling-phosphorylation of histone H2AX $(\gamma \mathrm{H} 2 \mathrm{AX})$-in HEK293T cells after $12 \mathrm{~h}$ treatment with different oxidant concentrations. ${ }^{* *} p<0.01$ ANOVA/Tukey, compared with the untreated control. Minimum of three replicates each. Vinculin was used as loading control for the Western blots. 

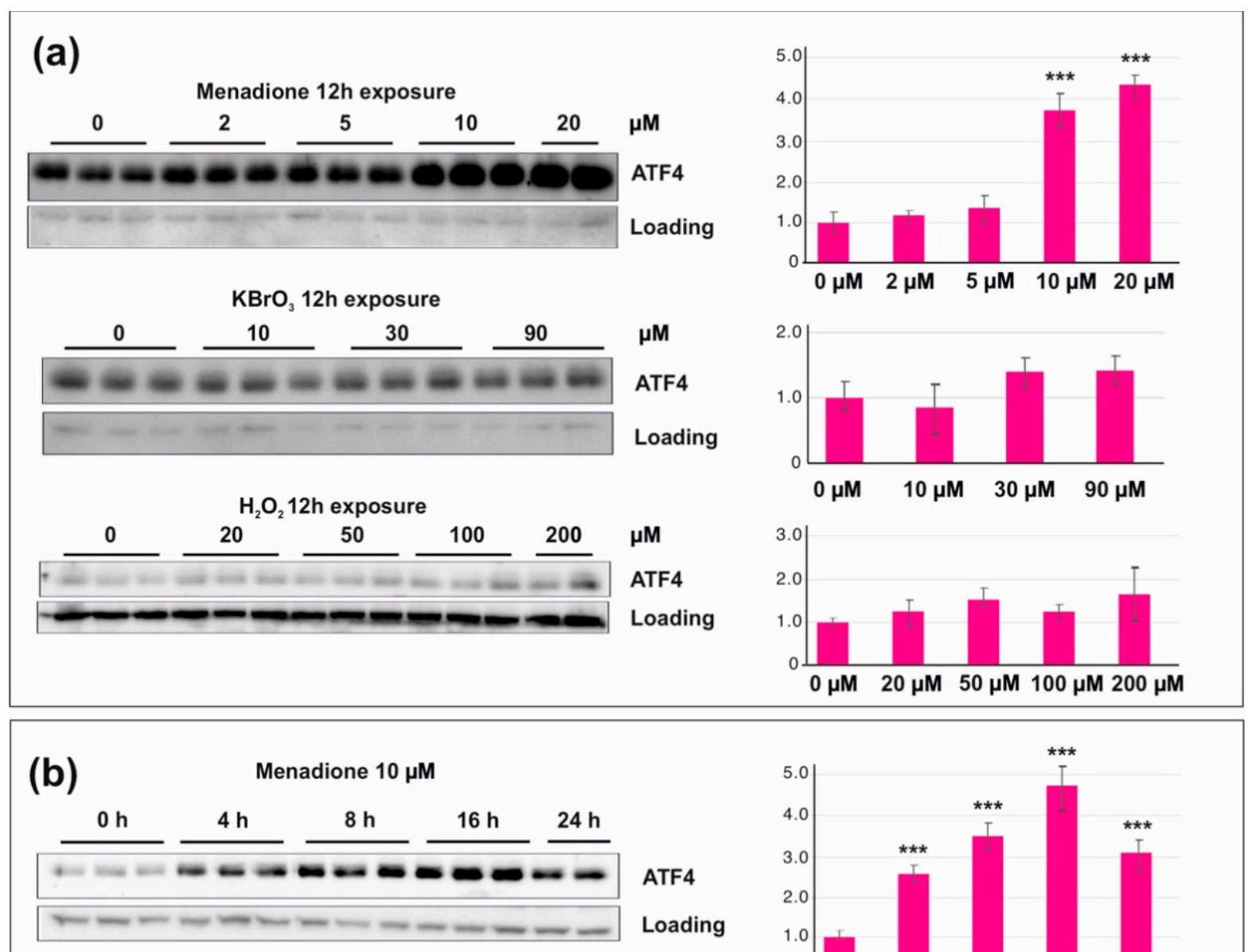

ATF4
Loading
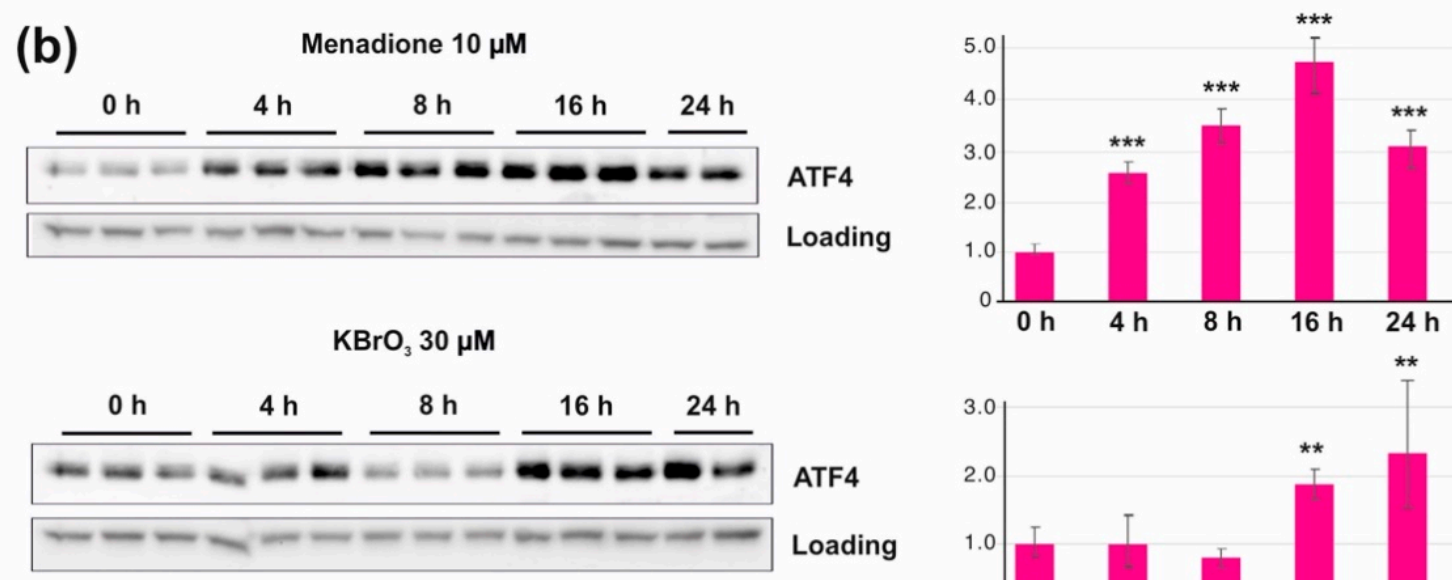

ATF4

Loading
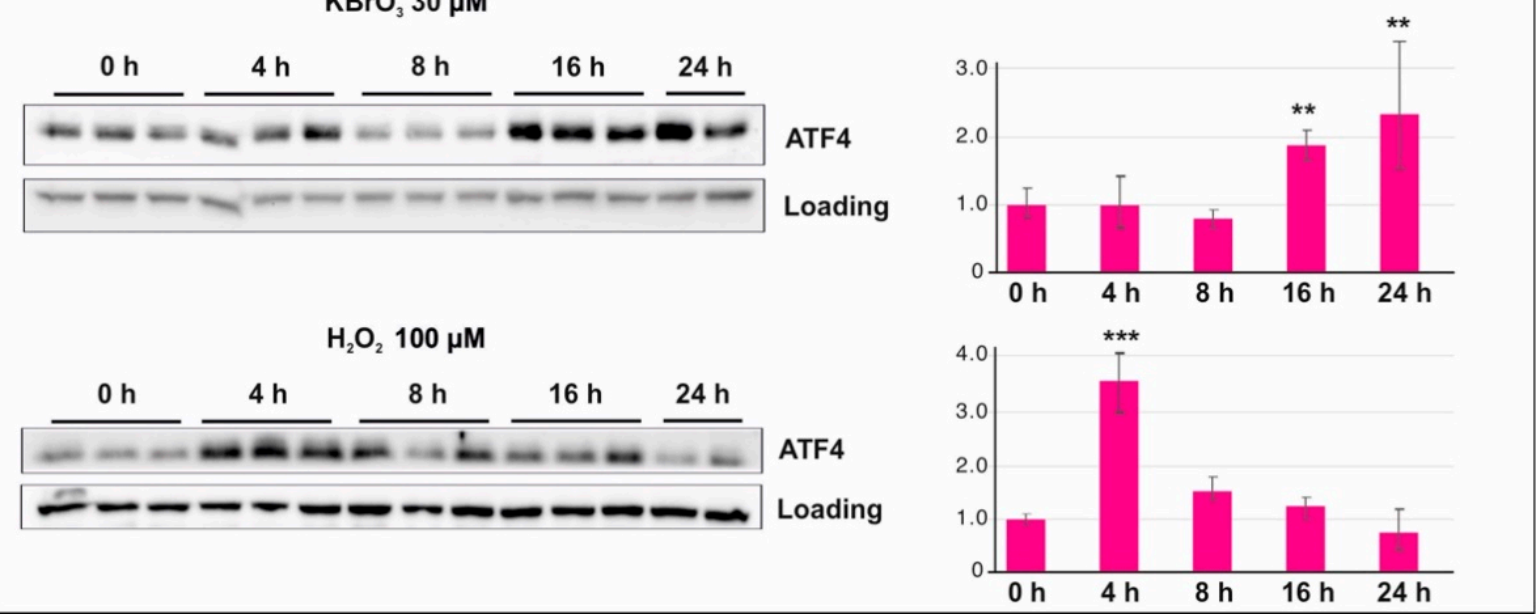

Figure 2. Integrated stress response (ISR) in HEK293T cells exposed to menadione, $\mathrm{KBrO}_{3}$, or $\mathrm{H}_{2} \mathrm{O}_{2}$. (a) ATF4 levels after $12 \mathrm{~h}$ exposure to increasing concentrations of oxidants. Note the dramatic increase after menadione treatment. (b) Menadione causes a rapid and persistent induction of ISR, whereas $\mathrm{KBrO}_{3}$ treated cells show a delayed response only after $16 \mathrm{~h}$ exposure. The $\mathrm{H}_{2} \mathrm{O}_{2}$ treatment results in a transient increase in ATF4 levels after $4 \mathrm{~h}$ exposure. VDAC and actin were used as a loading control. ${ }^{* *} p<0.01,{ }^{* * *} p<0.001$ ANOVA/Tukey, compared with the untreated control.

Despite their differential effects on DNA damage response (Figure 1d) and ISR activation (Figure 2), $10 \mu \mathrm{M}$ menadione, $30 \mu \mathrm{M}$ potassium bromate, and $100 \mu \mathrm{M}$ hydrogen peroxide were all able to halt cell proliferation at $24 \mathrm{~h}$ (Figure 1c). To obtain a more global view on the effects of these chemicals and the cause of the growth arrest, we performed a transcriptome analysis using an RNA-sequencing approach. The $24 \mathrm{~h}$ timepoint was chosen 
as a treatment end-point result to compare differences and similarities from the various oxidants. As potassium bromate is not rapidly turned over like $\mathrm{H}_{2} \mathrm{O}_{2}$ and is also not known to interfere with the mitochondrial respiratory chain as menadione does, thus avoiding downstream effects on the overall cellular metabolism, we took it as an example oxidant to study the recovery and subsequent response to a repeated ROS insult as an additional experiment. As an additional aspect, we have shown that $\mathrm{KBrO}_{3}$ induces specific changes in mtDNA replication, which we have not observed with the other two oxidants.

A $24 \mathrm{~h}$ treatment with menadione and potassium bromate resulted in a strikingly similar effect on gene expression, whereas $\mathrm{H}_{2} \mathrm{O}_{2}$ treatment caused a markedly different reaction in cells (Figure 3a). Cells treated with $\mathrm{KBrO}_{3}$ and allowed to recover for an additional $24 \mathrm{~h}$ were comparable to untreated cells, demonstrating that the oxidative exposure did not result in permanent alteration of gene expression. Interestingly, the gene expression changes in cells retreated with potassium bromate after the initial recovery did not correspond to cells treated only once. The similarity of the first-time $\mathrm{KBrO}_{3}$ and menadione treatment was caused by substantial reduction in general transcription activity (Figure 3b,c), whereas the hydrogen peroxide treatment resulted in differential up- and downregulation of dozens of genes (Figure 3d). Genes significantly upregulated in hydrogen peroxide-treated cells included antioxidant defense enzymes, such as SOD1 as well as glutathione peroxidases GPX1 and GPX8. Interestingly, neither mitochondrial SOD2 nor catalase (CAT), responsible for $\mathrm{H}_{2} \mathrm{O}_{2}$ elimination in mitochondria, were affected. In addition, $10 \mu \mathrm{M}$ menadione caused a slightly stronger reduction in transcript levels than $30 \mu \mathrm{M}$ potassium bromate (Figure 3e).

Despite the dramatic differences in the impact on the global gene expression of menadione and $\mathrm{KBrO}_{3}$ compared to the $\mathrm{H}_{2} \mathrm{O}_{2}$ treatment, the effects of the three different oxidant exposures had some common outcomes on negatively regulated genes (Figure 4a). Notably, not a single positively regulated gene was shared between the treatments. All three treatments resulted in downregulation of cell cycle (Figure $4 \mathrm{~b}$ ), as evident also from the cessation of cell proliferation (Figure 1c). Both menadione and potassium bromate treatments also resulted in general downregulation of gene expression (Figure 4c), which was not evident after hydrogen peroxide treatment. In addition, $\mathrm{KBrO}_{3}$-treated cells showed specific impacts on translation, specifically the downregulation of translation initiation, nonsense-mediated decay, and post-translational modification (Figure 4d), which were not seen in cells treated with menadione. In fact, apart from general transcription inhibition, menadione-treated cells showed only a weak impact on other specific cellular processes (Figure 4e). In contrast to menadione and $\mathrm{KBrO}_{3}, \mathrm{H}_{2} \mathrm{O}_{2}$-treated cells showed specific and substantial upregulation of a number of cellular processes, including amino acid metabolism, protein catabolism, hypoxia response, and mitochondrial biogenesis (Figure 4f).

As pointed out earlier, ATF4-mediated integrated stress response can be triggered by a number of upstream signals. The most logical one upon oxidative stress would be the unfolded protein response [31]. Oxidation of disulfide bonds in proteins results in the accumulation of misfolded proteins, triggering PERK, a transmembrane protein kinase that phosphorylates the $\alpha$-subunit of translation initiation factor 2 (eIF2 $\alpha$ ). Phosphorylation of eIF2 $\alpha$ in turn increases the translation of ATF4 mRNA while otherwise generally inhibiting protein synthesis. Interestingly, menadione exposure did not increase eIF2 $\alpha$ phosphorylation (Figure 5a) in HEK293T cells in similar fashion to UV exposure (Figure 5b). However, menadione treatment was able to overcome the decrease in the eIF $2 \alpha$ phosphorylation caused by PERK inhibitor, maintaining steady-state levels of the phosphorylated protein (Figure 5a). Oddly, the same was not observed for UV treatment (Figure 5b). 

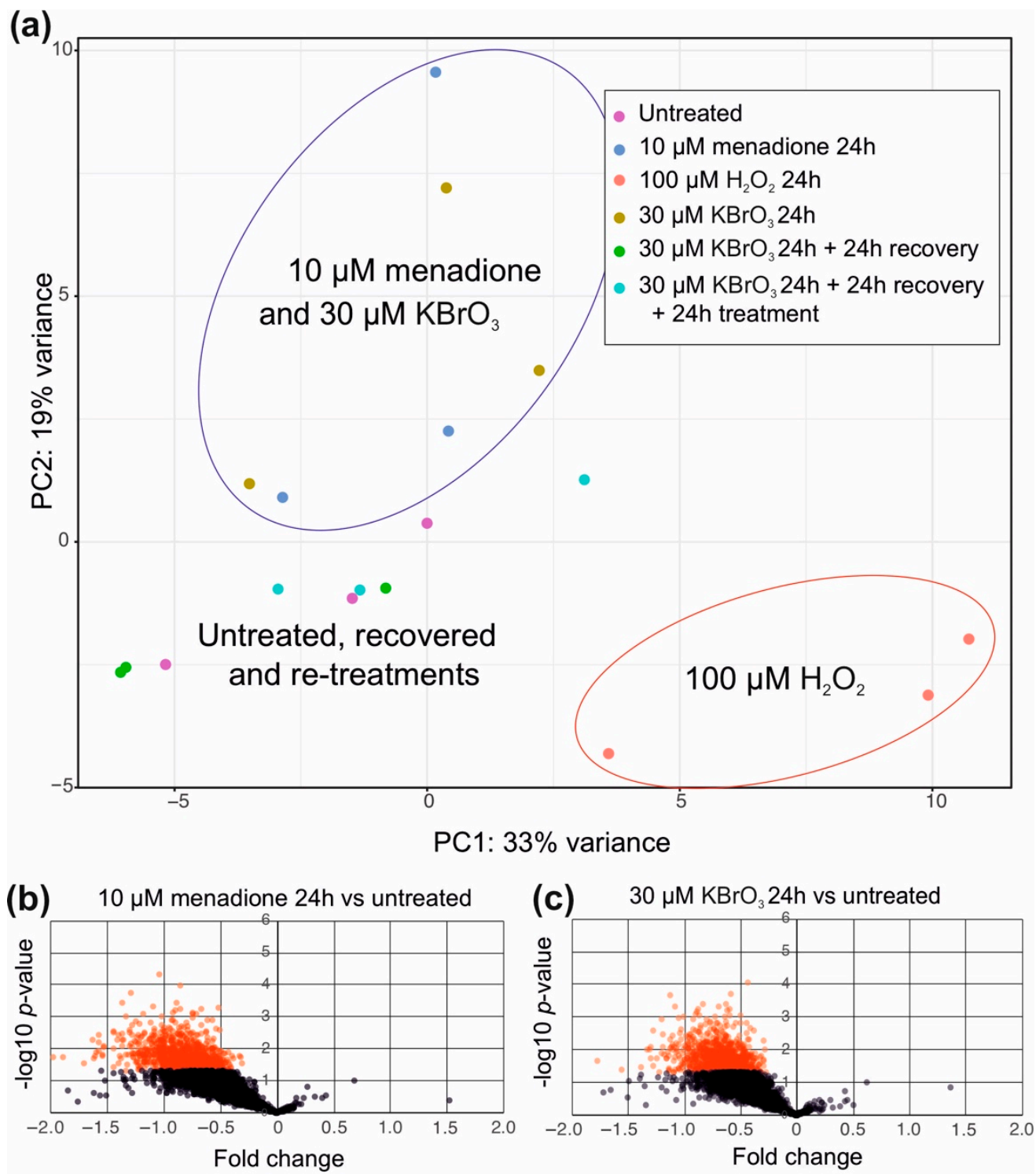

(d)

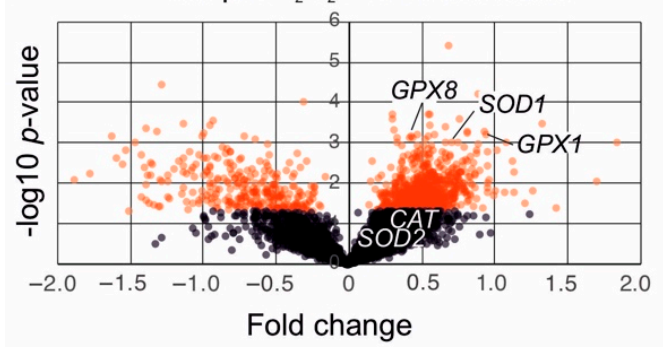

(e)

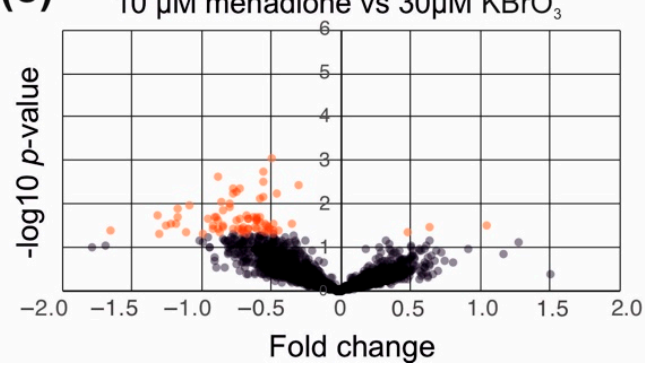

Figure 3. Global gene expression changes during and after oxidative stress. (a) Principal component analysis (PCA) of the treated cells as indicated in the legend. Menadione and $\mathrm{KBrO}_{3}$ exposure cause similar changes in the transcriptome, whereas $\mathrm{H}_{2} \mathrm{O}_{2}$ treated cells differ from these as well as from control cells. Untreated controls, cells recovered from $\mathrm{KBrO}_{3}$ exposure for $24 \mathrm{~h}$, and cells retreated with $\mathrm{KBrO}_{3}$ after recovery also cluster together. (b) A volcano plot showing down(left) and up- (right) regulated genes after $24 \mathrm{~h}$ menadione treatment. The y-axis indicates the inverse log10 $\mathrm{t}$-test $p$-value. Genes having $p$-values below 0.05 are shown in red. (c) The $\mathrm{KBrO}_{3}$-treated cells show a similar, general reduction in gene expression as the menadione-treated cells. (d) In contrast, $\mathrm{H}_{2} \mathrm{O}_{2}$ treatment results in differential up- and downregulation of dozens of genes. Antioxidant defense genes, such as SOD1 and GPXs are among the upregulated genes. (e) $10 \mu \mathrm{M}$ menadione treatment causes a more exaggerated reduction in transcriptional activity than $30 \mu \mathrm{M} \mathrm{KBrO}_{3}$. 


\section{Downregulated genes}

(a)

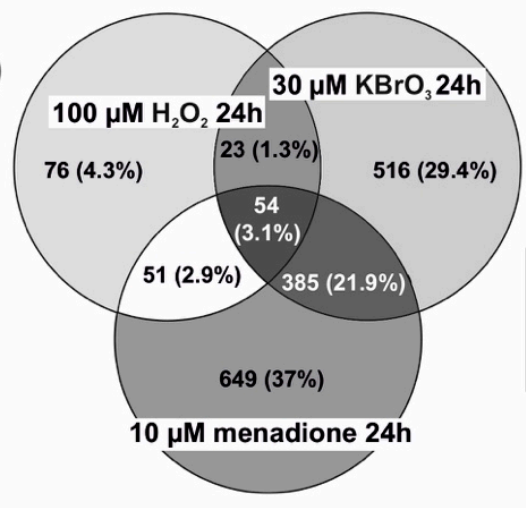

(f)

Upregulated in $\mathrm{H}_{2} \mathrm{O}_{2}$
$\begin{aligned} & \text { amino acid metabolism } \\ & \text { proteosomal, ubiquitin-dependent catabolic processes } \\ & \text { hypoxia response } \\ & \text { mitochondrion }\end{aligned}$

(b) Downregulated in all

re-entry into mitotic cell cycle

positive regulation of protein phosphorylation

positive regulation of phosphorylation

(c)

Downregulated in $\mathrm{KBrO}_{3}$ and menadione

regulation of transcription by RNA polymerase II transcription regulation and coregulation

(d)

Downregulated in $\mathrm{KBrO}_{3}$

nonsense-mediated decay

translation initiation

protein targeting to membrane

(e) Downregulated in menadione

glucose import

tight junction assembly

mitotic chromosome condensation

Figure 4. Different oxidative insults have common features. (a) A Venn diagram showing the number of common and private, significantly down-regulated genes after menadione, $\mathrm{KBrO}_{3}$, or $\mathrm{H}_{2} \mathrm{O}_{2}$ treatment. (b) Among the 54 genes downregulated after the exposure to each of the three chemicals were genes that are involved in cell cycle regulation and cell signaling. (c) Both menadione- and $\mathrm{KBrO}_{3}$-treated cells showed general inhibition of transcription, while (d) $\mathrm{KBrO}_{3}$ alone also induced downregulation of translation. (e) Menadione had relatively few privately affected processes, among these glucose imports. The 76 genes downregulated in $\mathrm{H}_{2} \mathrm{O}_{2}$-treated cells did not show any significant enrichment of specific cellular processes. (f) In contrast, $\mathrm{H}_{2} \mathrm{O}_{2}$-treated cells showed a significant upregulation of genes involved in amino acid metabolism, hypoxia response and protein catabolism.

(a)

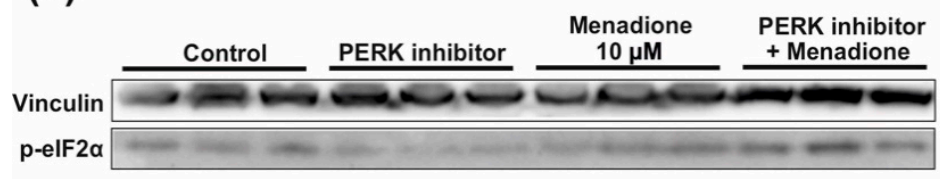

(b)

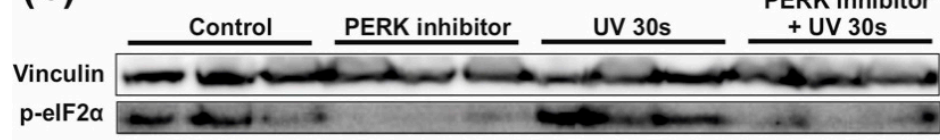

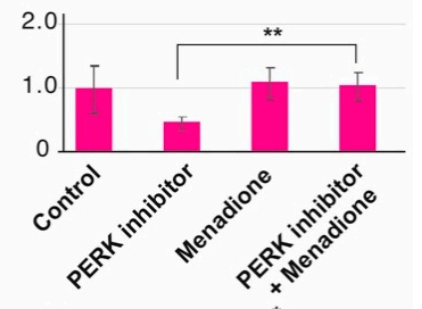

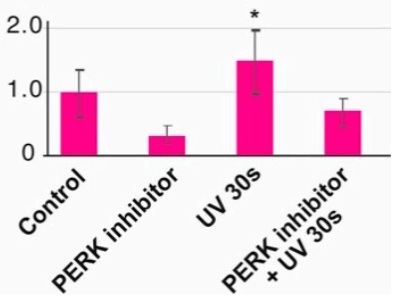

Figure 5. ISR upstream signals after menadione treatment. (a) Despite rapid upregulation of ATF4 levels, eIF2 $\alpha$ phosphorylation is not increased in cells treated with menadione for $8 \mathrm{~h}$. While a PERK inhibitor abolishes eIF2 $\alpha$ phosphorylation in untreated cells, steady-state levels are also maintained in menadione-treated cells in the presence of the inhibitor. (b) To validate the functionality of the antibody as well as the existence of PERK-eIF2 $\alpha$ signaling in HEK293T cells, the cells were exposed to $1.34 \mathrm{~mJ} / \mathrm{cm}^{2} \mathrm{UVB}(305 \mathrm{~nm})$ for $30 \mathrm{~s}$. Addition of PERK inhibitor $4 \mathrm{~h}$ prior the exposure prevented eIF2 $\alpha$ phosphorylation. Vinculin was used as a loading control. ${ }^{*} p<0.05,{ }^{* *} p<0.01$ ANOVA/Tukey.

As we had used potassium bromate successfully to induce mtDNA damage and subsequent changes in the replication mechanisms, we next compared the effects of the different oxidants on the replication intermediates $3 \mathrm{~kb}$ downstream of the main replication origin (Figure 6). The reason for investigating this region was that it allowed us to compare 
the partly single-stranded mtDNA replication intermediates arising from the housekeeping, strand-asynchronous replication mechanism with double-stranded DNA replication intermediates, that are typical for genomic stress [15-17]. In line with our previous work, only the $\mathrm{KBrO}_{3}$ treatment was able to elicit a change in the mtDNA replication pattern after $24 \mathrm{~h}$ treatment.

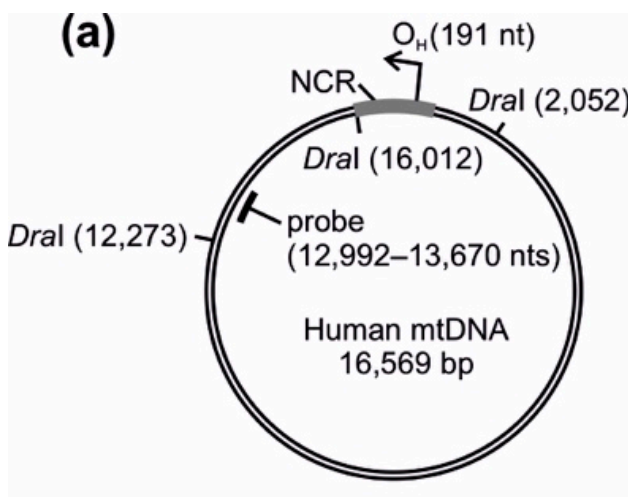

(b)
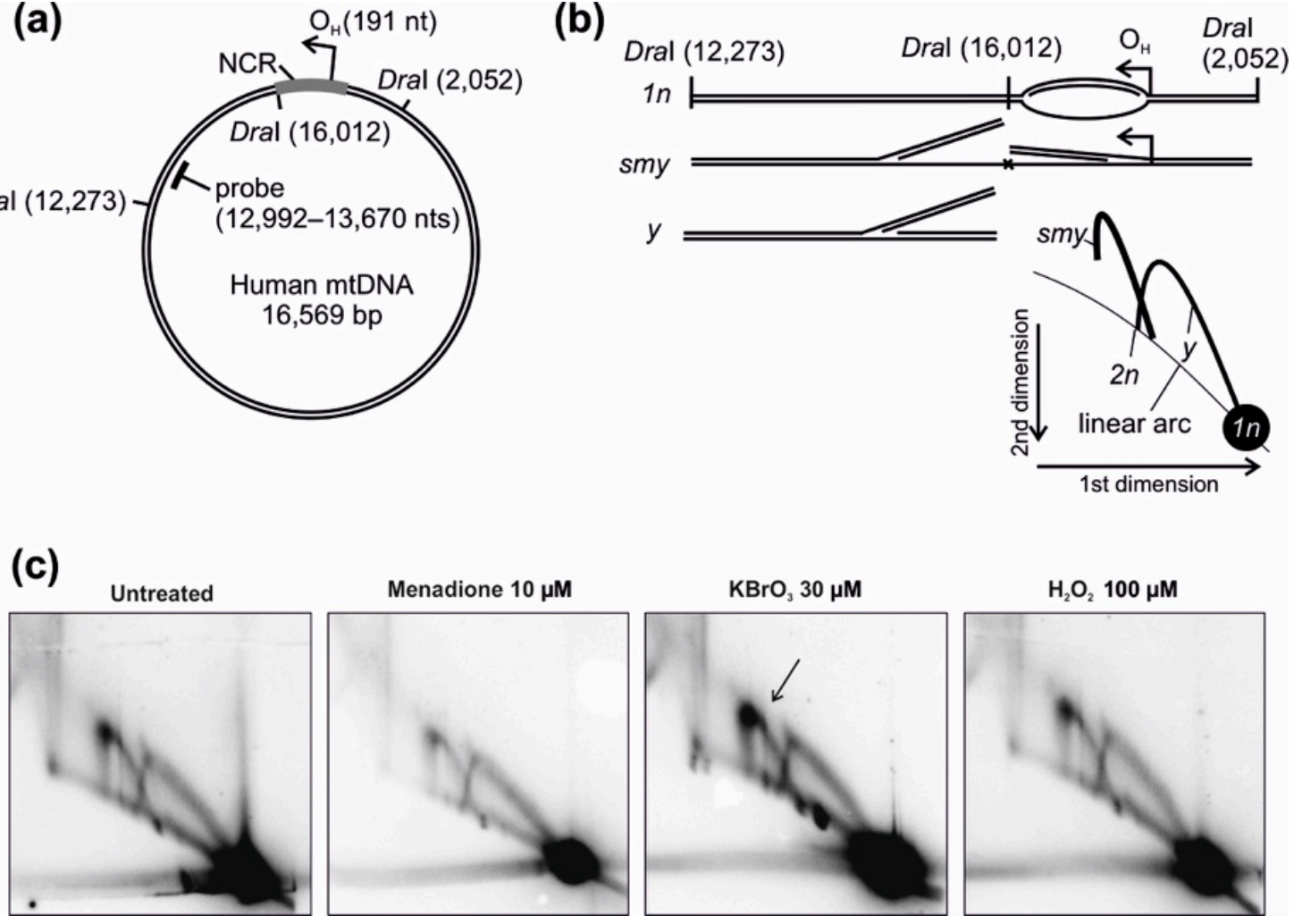

Figure 6. Modulation of mitochondrial DNA replication during oxidant exposure. (a) Schematic diagram of human mtDNA showing the investigated genomic region. (b) Interpretation of the 2D-AGE pattern. The probed fragment is downstream of the main replication origin $\mathrm{O}_{\mathrm{H}}$. Restriction site blockage due to single-strandedness or RNA incorporation on the lagging strand will give rise to slow moving $\mathrm{y}$-arc (smy) whereas double-stranded DNA replication intermediates migrate the y-arc (y). (c) 2D-AGE of DraI-digested mtDNA from untreated control cells, cells treated with $10 \mu \mathrm{M}$ menadione, cells treated with $30 \mu \mathrm{M} \mathrm{KBrO}_{3}$, and from cells treated with $100 \mu \mathrm{M} \mathrm{H}_{2} \mathrm{O}_{2}$ for $24 \mathrm{~h}$. Arrowhead points to the increase in the partly single-stranded mtDNA replication intermediates in $\mathrm{KBrO}_{3}$-treated cells (see $[15,16]$ for more details).

We were also interested to see if an initial exposure to oxidative stress is able to ameliorate the effects of a second ROS insult, a phenomenon known as (mitochondrial) hormesis [3,32]. Based on our transcriptome analyses, 293 cells recovered well within $24 \mathrm{~h}$ after an initial insult with $30 \mu \mathrm{M}$ potassium bromate (Figures $3 \mathrm{a}$ and $7 \mathrm{a}$ ). Some genes remained downregulated compared to untreated cells, but no significant regulation of specific cellular processes was detected in the GO-term analyses. Interestingly, retreatment of the recovered cells with the same concentration of $30 \mu \mathrm{M} \mathrm{KBrO}$, induced a less dramatic impact in cells than the initial treatment. Although retreated cells also showed an overall reduction in their gene expression activity (Figure $7 \mathrm{~b}$ ), this effect was smaller than the one caused by the first exposure (Figure 7c). Among the cellular processes that did not change or were upregulated during the second exposure but not the first, were some modules of gene regulation (especially mRNA splicing), protein catabolism and-interestingly - mitochondrial- as well as DNA-repair-related pathways. The DNA damage-associated genes included known repair enzymes, such as APEX1 (Figure 7d) but also the mitochondrial exonuclease MGME1 required for the degradation of damaged mtDNA [33]. 
(a) $24 \mathrm{~h}$ recovery vs. untreated

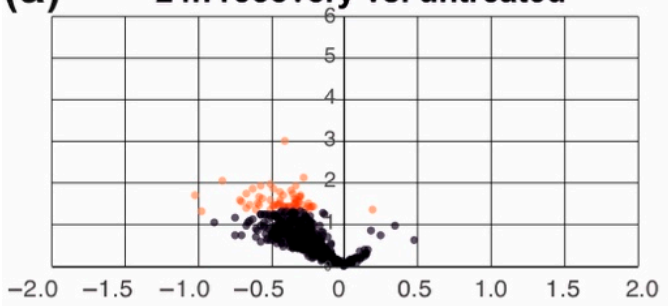

(c) $24 \mathrm{~h}$ re-insult vs. first $30 \mu \mathrm{M} \mathrm{KBrO}{ }_{3}$ exposure

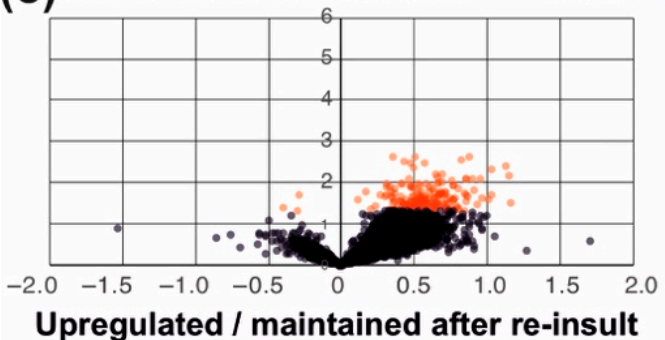

transcription regulation and coregulation proteosomal, ubiquitin-dependent catabolic processes mitochondrion

DNA repair (b)

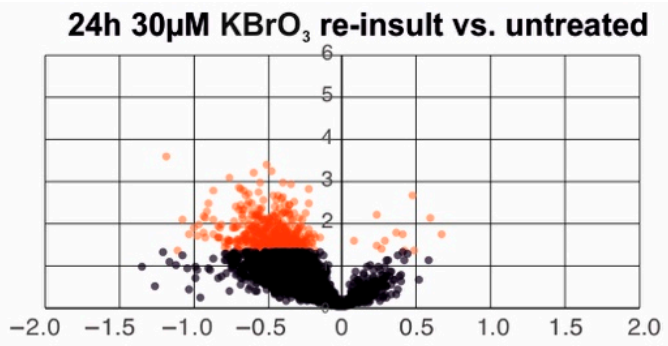

(d) DNA damage and repair

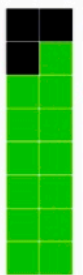

poly(ADP-ribose) polymerase (PARP4) replication timing regulatory factor (RIF1) mitochondrial genome maintenance exonuclease 1 (MGME1) pre-mRNA processing factor 19 (PRPF19) ring finger protein 8 (RNF8) ubiquiting conjugating enzyme E2W (UBE2W) ATRX apurinic/apyrmidinic endodeoxyribonuclease 1 (APEX1)

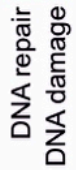

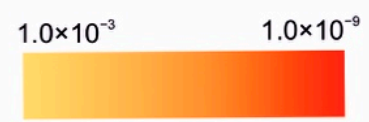

FDR q-value

Figure 7. Hormetic effects in cells exposed to oxidative stress. (a) Gene expression differences between cells after 24 h recovery of $30 \mu \mathrm{M} \mathrm{KBrO}_{3}$ treatment and untreated controls. The $\mathrm{x}$-axis indicates the fold change and the $\mathrm{y}$-axis the inverse $\log 10$ t-test $p$-value. Genes with $p$-values below 0.05 are shown in red. The recovering cells still show several downregulated genes, but no specific pathways or processes are affected. (b) Retreatment with $30 \mu \mathrm{M} \mathrm{KBrO} \mathrm{K}_{3}$ after the recovery induces a similar, but milder reduction in gene expression as seen upon the first insult. (c) Retreated cells show the specific maintenance of pathways and cellular processes linked to gene expression, mitochondrial function and DNA repair. (d) Among the maintained DNA damage-associated genes are repair enzymes such as APEX1, but also the mtDNA-degrading exonuclease MGME1.

\section{Discussion}

The study of free radicals and their effects in living organisms continues to be a hot topic in biology. Oxidative damage of biomolecules is detrimental to the cell and has been traditionally viewed as a pathological mechanism per se [3,34]. This is because pathological alterations of normal cellular functions, especially the dysfunction of the mitochondrial electron transport chain, typically result in increased oxidative stress, resulting in tissue damage. However, oxidative stress occurs frequently under normal physiological conditions and plays an important regulatory as well as developmental role in most organisms. The balance between normal physiological regulation and pathology is highly interesting as it has evolutionary consequences on e.g., life history strategies [35]. Most recently, there has been interest in chronic oxidative stress caused by ionizing radiation during space exploration, which could impact the health of astronauts on prolonged spaceflights [36], including missions to Mars.

There are a number of ways to experimentally study oxidative stress. The most physiological method might be the knockout or impairment of antioxidant defense genes [37], which allows targeting oxidative stress to specific cell compartments or tissues [38]. However, much of the work on generalizable, basic mechanisms is conducted using cultured cell models, where oxidative stress is induced by exposure to various chemicals. Some, such as the inhibitors of the ETC, are effective ROS generators, but cause major negative side-effects due to the poisoning of mitochondria [39]. In this study, we have compared 
the effects of three oxidants that are commonly used in experimentation but are not direct ETC poisons and have quite different modes of actions. At the right concentrations, all three, menadione, potassium bromate, and hydrogen peroxide, are non-lethal but able to block cell proliferation (Figure 1c), but there are both subtle and major differences in the oxidative stress they induce.

Of the compared chemicals, menadione stands out because of its toxicity. Although it is often assumed that menadione generates mitochondrial superoxide by bypassing of electrons from the ETC to oxygen, the chemical has clearly a broader impact on cells. In fact, our observations, including a massive activation of nuclear DNA damage signaling (Figure 1c) and high levels of oxidative stress in the cytoplasm (Figure 1a), confirm previous observations of ROS formation at multiple sites in cells treated with menadione $[11,19]$. The mitochondrial ROS stress by $\mathrm{KBrO}_{3}$ correlates with its effects on mtDNA replication, while menadione does not influence mtDNA maintenance (Figure 6 and [16]). This apparent mitochondrial specificity of $\mathrm{KBrO}_{3}$ is counterintuitive, as the mitochondrial membrane potential and/or $\mathrm{pH}$ gradient should expel the negatively charged bromate from the organelle or retain it in the intermembrane space. This discrepancy between nuclear and mitochondrial genomes might therefore be caused by a more efficient repair in the nucleus rather than more severe DNA damage in mitochondria. However, the relatively small effects of $\mathrm{H}_{2} \mathrm{O}_{2}$ on cytoplasmic or mitochondrial ROS stress were not surprising due to the generally rapid turnover of the molecule [14]. Of note, HEK293T cells are challenging for fluorescent measurements due to their tendency to detach during washes or clumping in the cell suspensions, causing some sample-to-sample variation in the measurements (Figure 1a,b).

One of the most important pathways sensing ROS stress is the integrated stress response, or ISR [30]. ISR was activated by all three oxidants, although the persistence and dynamics of the response differed (Figure 2). As with the activation of nuclear DNA damage signaling, menadione was the most aggressive of the tested chemicals, causing rapid and persistent activation of ISR even at low concentrations. Interestingly, ISR showed a delayed response to $\mathrm{KBrO}_{3}$, possibly indicating a more slowly developing and chronic oxidative stress. Although we assumed that the ISR activation was PERK- and eIF2 $\alpha$ dependent, menadione-treated cells had control levels of eIF $2 \alpha$ phosphorylation, which were also maintained in the presence of a PERK inhibitor (Figure 5). Our observations underscore the notion that the textbook views of ISR and eIF2 $\alpha$ phosphorylation probably do not represent the full picture, as pointed out recently [40]. However, in line with the unfolded-protein-response-induced ISR [31], $\mathrm{KBrO}_{3}$-treated cells also showed a specific inhibition of protein synthesis apart for the transcriptional shutdown (Figure 4d).

Regardless of the nuances of ISR activation, menadione and $\mathrm{KBrO}_{3}$ treatments resulted in global downregulation of transcription (Figure $3 b, c$ ), as expected from a ROS-induced stress response [40]. The biological significance of an unfolded protein response causing shutdown of transcription and translation is to prevent the accumulation of defective proteins in the ER, while trying to restore the redox homeostasis [31]. In contrast, hydrogen peroxide treatment resulted in differential regulation of dozens of genes (Figure 3d). It is likely that our approach of treating the cells with one single large bolus of $\mathrm{H}_{2} \mathrm{O}_{2}$, causing immediate damage and being subsequently lost in the various sinks, induced a different result than a persistent exposure to more stable concentrations of the oxidant, which could be achieved e.g., by a glucose oxidase approach [14]. However, our experiment showed that the response to oxidative stress consists of more than just repair and recovery of the damage, which could reveal the mode of action of the different oxidants. While menadione-, $\mathrm{KBrO}_{3}$ - and $\mathrm{H}_{2} \mathrm{O}_{2}$-exposed cells were all arrested at $24 \mathrm{~h}$ post treatment (Figures $1 \mathrm{c}$ and $4 \mathrm{~b}$ ), only $\mathrm{H}_{2} \mathrm{O}_{2}$ cells showed any adaptation or repair by amplifying their antioxidant defenses (examples in Figure 3d). Interestingly, these are mainly cytoplasmic enzymes, which together with the impacts on other cytosolic or extracellular metabolic functions (Figure 4f), suggests that extracellular $\mathrm{H}_{2} \mathrm{O}_{2}$ is unable to penetrate most cellular compartments. This feature of $\mathrm{H}_{2} \mathrm{O}_{2}$ could also explain the lack of nuclear DNA damage signaling (Figure 1c). 
The fact that $\mathrm{KBrO}_{3}$-treated cells returned to the control state $24 \mathrm{~h}$ after the removal of the drug (Figures 3a and 7a), suggests that the effects seen in cells after $24 \mathrm{~h}_{2} \mathrm{O}_{2}$ treatment are not only about recovery and repair. Despite the numerous $\mathrm{H}_{2} \mathrm{O}_{2}$ sinks in cells and media, it is likely that the treatment sets in motion a cascade of events, interfering with a number of metabolic pathways, while not triggering a similar integrated stress response to those of menadione and potassium bromate. This observation emphasizes the fact that the differences in ROS responses are likely to be determined by a set of specific oxidative reactions. Both the location and the order of oxidative reactions are plausible causes of the difference between physiological signaling and an all-out stress response. It is worth pointing out that we here have focused on HEK293T cells, and that the ROS responses in other established cells lines, not to mention more natural primary cells or tissues, are likely to be different.

Finally, we looked at the potential hormetic effects induced by ROS exposure. We chose potassium bromate for this trial due to its lower toxicity compared to menadione, as it did not, for example, induce a nuclear DNA damage response (Figure 1c). At the same time, its dose was easier to control than that of $\mathrm{H}_{2} \mathrm{O}_{2}$, and it was able to cause stable oxidative stress in cells, as judged from the ISR activation (Figure 2). The experiment should be considered as a proof-of-concept, as it is clear that mechanistic elucidation of the priming of hormesis would be a project on its own. However, our observations provide an interesting insight into the potential mechanisms of hormesis activation. Firstly, cells recovering for $24 \mathrm{~h}$ from an initial $\mathrm{KBrO}_{3}$ treatment were basically comparable with untreated cells (Figures $3 \mathrm{a}$ and $7 \mathrm{a}$ ), without any signs of compensatory effects on cellular processes. This indicates that the clearing and repair of damaged cell components as well as restoration of normal cellular functions occurs rapidly after the removal of the drug. Remarkably, a second oxidative insult after recovery from the initial stress did induce silencing of gene expression (Figure $7 \mathrm{~b}$ ), corresponding to ISR activation, but the response was muffled in comparison to the first exposure (Figures $3 \mathrm{a}$ and $7 \mathrm{c}$ ). While the retreated cells did not upregulate any specific ROS-stress related genes, they maintained the expression of groups of genes, which might enable adaptation to protein or DNA damage (Figure 7c). Among the DNA-metabolism-linked gene products was the mitochondrial MGME1 nuclease required for turnover of damaged mtDNA [33], which we have recently shown to be associated with damage-induced changes in mtDNA replication [17]. $\mathrm{As}^{\mathrm{KBrO}_{3}}$ was the only oxidant capable of inducing changes in mtDNA replication (Figure 6), this is highly interesting and the role of MGME1 in mtDNA damage response warrants further examination.

The recovery-retreatment experiment also reveals interesting insights into the priming of potential hormetic effects in cells. After recovery from the initial $\mathrm{KBrO}_{3}$ insult, the cells did not show significant alterations in gene expression patterns compared to untreated controls (Figures $3 \mathrm{a}$ and 7a), but still reacted differently to a renewed oxidative stress. While it is possible that the first treatment left behind some cellular memory in the form of protein modifications, a more plausible explanation is epigenetic modifications caused by the stress, which will influence the gene expression response in the following cell generations. Various types of stress, including oxidative stress [41], are known to induce epigenetic changes in cells. It is noteworthy that oxidative stress has been also linked with epigenetic changes seen in ageing individuals [42]. While ageing is generally considered as deleterious to the individual, it is plausible that some of the epigenetic changes represent physiologically meaningful adaptations to oxidative metabolism and environmental stress.

\section{Conclusions}

In the presented work, we compared the effects of menadione, $\mathrm{KBrO}_{3}$, and $\mathrm{H}_{2} \mathrm{O}_{2}$ on DNA damage response, integrated stress response and global gene regulation in HEK293T cells. Despite some similarities, the responses to the three oxidants differed markedly, urging caution when comparing studies using different sources of oxidative stress. We also observed that an initial oxidative stress can mitigate the consequences of a subsequent oxidative insult. As the first oxidant exposure did not cause significant long-lasting effect on 
gene expression, it is plausible that the protection is caused by epigenetic modifications that have primed the cells to better tolerate or repair oxidative damage. The actual mechanisms of the hormetic effect should be investigated in future studies.

Supplementary Materials: The following are available online at https:/ / www.mdpi.com/article/10 .3390/ cells10051075/s1, Table S1. Transcriptome data.

Author Contributions: Conceptualization, S.G. and J.L.O.P.; methodology, S.G., P.T., T.W., and C.M.; validation, S.G. and P.T.; formal analysis, S.G., P.T., T.W., and C.M.; investigation, S.G., P.T., T.W., and C.M.; resources, S.G. and J.L.O.P.; data curation, S.G. and J.L.O.P.; writing-original draft preparation, S.G. and J.L.O.P.; writing-review and editing, P.T., T.W., C.M., S.G., and J.L.O.P.; visualization, J.L.O.P.; supervision, S.G. and J.L.O.P.; project administration, S.G. and J.L.O.P.; funding acquisition, S.G. and J.L.O.P. All authors have read and agreed to the published version of the manuscript.

Funding: This work was supported by the Jane and Aatos Erkko Foundation, the Finnish Cultural Foundation, and the Academy of Finland.

Institutional Review Board Statement: Not applicable.

Informed Consent Statement: Not applicable.

Data Availability Statement: The data presented in this study are available in the article and its Supplementary Material.

Acknowledgments: We would like to thank Maja Boziç for her assistance in the laboratory.

Conflicts of Interest: The authors declare no conflict of interest. The funders had no role in the design of the study; in the collection, analyses, or interpretation of data; in the writing of the manuscript, or in the decision to publish the results.

\section{References}

1. Rozantsev, E.G.; Loshadkin, D.V. The history and modern problems of free radical chemistry. 100 years of free radical chemistry. Des. Monomers Polym. 2001, 4, 281-300. [CrossRef]

2. Murphy, M.P.; Holmgren, A.; Larsson, N.-G.; Halliwell, B.; Chang, C.J.; Kalyanaraman, B.; Rhee, S.G.; Thornalley, P.J.; Partridge, L.; Gems, D.; et al. Unraveling the Biological Roles of Reactive Oxygen Species. Cell Metab. 2011, 13, 361-366. [CrossRef]

3. Pohjoismäki, J.L.; Goffart, S. The role of mitochondria in cardiac development and protection. Free. Radic. Biol. Med. 2017, 106, 345-354. [CrossRef]

4. Liochev, S.I.; Fridovich, I. Superoxide and iron: Partners in crime. Iubmb Life 1999, 48, 157-161. [CrossRef]

5. Kauppila, T.E.; Kauppila, J.H.; Larsson, N.-G. Mammalian Mitochondria and Aging: An Update. Cell Metab. $2017,25,57-71$. [CrossRef]

6. Huang, T.-T.; Carlson, E.J.; Raineri, I.; Gillespie, A.M.; Kozy, H.; Epstein, C.J. The use of transgenic and mutant mice to study oxygen free radical metabolism. Ann. N. Y. Acad. Sci. 1999, 893, 95-112. [CrossRef]

7. Azzam, E.I.; Jay-Gerin, J.-P.; Pain, D. Ionizing radiation-induced metabolic oxidative stress and prolonged cell injury. Cancer Lett. 2012, 327, 48-60. [CrossRef] [PubMed]

8. Frei, B.; Winterhalter, K.H.; Richter, C. Menadione-(2-Methyl-1,4-Naphthoquinone) Dependent Enzymatic Redox Cycling and Calcium Release by Mitochondria. Biochemistry-Us 1986, 25, 4438-4443. [CrossRef]

9. Comporti, M. Three models of free radical-induced cell injury. Chem. Interact. 1989, 72, 1-56. [CrossRef]

10. Halilovic, A.; Schmedt, T.; Benischke, A.-S.; Hamill, C.; Chen, Y.; Santos, J.H.; Jurkunas, U.V. Menadione-Induced DNA Damage Leads to Mitochondrial Dysfunction and Fragmentation During Rosette Formation in Fuchs Endothelial Corneal Dystrophy. Antioxidants Redox Signal. 2016, 24, 1072-1083. [CrossRef]

11. Loor, G.; Kondapalli, J.; Schriewer, J.M.; Chandel, N.S.; Hoek, T.L.V.; Schumacker, P.T. Menadione triggers cell death through ROS-dependent mechanisms involving PARP activation without requiring apoptosis. Free. Radic. Biol. Med. 2010, 49, 1925-1936. [CrossRef] [PubMed]

12. Tzeng, W.-F.; Lee, J.-L.; Chiou, T.-J. The role of lipid peroxidation in menadione-mediated toxicity in cardiomyocytes. J. Mol. Cell. Cardiol. 1995, 27, 1999-2008. [CrossRef]

13. Ransy, C.; Vaz, C.; Lombes, A.; Bouillaud, F. Use of $\mathrm{H}_{2} \mathrm{O}_{2}$ to Cause Oxidative Stress, the Catalase Issue. Int. J. Mol. Sci. 2020, 21, 9149. [CrossRef]

14. Marinho, H.S.; Cyrne, L.; Cadenas, E.; Antunes, F. $\mathrm{H}_{2} \mathrm{O}_{2}$ delivery to cells: Steady-state versus bolus addition. Methods Enzymol. 2013, 526, 159-173.

15. Torregrosa-Muñumer, R.; Forslund, J.M.E.; Goffart, S.; Pfeiffer, A.; Stojkovič, G.; Carvalho, G.; Al-Furoukh, N.; Blanco, L.; Wanrooij, S.; Pohjoismäki, J.L.O. PrimPol is required for replication reinitiation after mtDNA damage. Proc. Natl. Acad. Sci. USA 2017, 114, 11398-11403. [CrossRef] 
16. Torregrosa-Muñumer, R.; Goffart, S.; Haikonen, J.A.; Pohjoismäki, J.L.O. Low doses of ultraviolet radiation and oxidative damage induce dramatic accumulation of mitochondrial DNA replication intermediates, fork regression, and replication initiation shift. Mol. Biol. Cell 2015, 26, 4197-4208. [CrossRef]

17. Torregrosa-Muñumer, R.; Hangas, A.; Goffart, S.; Blei, D.; Zsurka, G.; Griffith, J.; Kunz, W.S.; Pohjoismäki, J.L.O. Replication fork rescue in mammalian mitochondria. Sci. Rep. 2019, 9, 1-16. [CrossRef]

18. Kawanishi, S.; Murata, M. Mechanism of DNA damage induced by bromate differs from general types of oxidative stress. Toxicolology 2006, 221, 172-178. [CrossRef]

19. Criddle, D.N.; Gillies, S.; Baumgartner-Wilson, H.K.; Jaffar, M.; Chinje, E.C.; Passmore, S.; Chvanov, M.; Barrow, S.; Gerasimenko, O.V.; Tepikin, A.V.; et al. Menadione-induced Reactive Oxygen Species Generation via Redox Cycling Promotes Apoptosis of Murine Pancreatic Acinar Cells. J. Biol. Chem. 2006, 281, 40485-40492. [CrossRef]

20. Bindoli, A.; Fukuto, J.M.; Forman, H.J. Thiol Chemistry in Peroxidase Catalysis and Redox Signaling. Antioxidants Redox Signal. 2008, 10, 1549-1564. [CrossRef]

21. Waypa, G.B.; Marks, J.D.; Guzy, R.; Mungai, P.T.; Schriewer, J.; Dokic, D.; Schumacker, P.T. Hypoxia Triggers Subcellular Compartmental Redox Signaling in Vascular Smooth Muscle Cells. Circ. Res. 2010, 106, 526-535. [CrossRef] [PubMed]

22. Axten, J.M.; Medina, J.R.; Feng, Y.; Shu, A.; Romeril, S.P.; Grant, S.W.; Li, W.H.H.; Heerding, D.A.; Minthorn, E.; Mencken, T.; et al. Discovery of 7-Methyl-5-(1-\{[3-(trifluoromethyl)phenyl]acetyl\}-2,3-dihydro-1H-indol-5-yl)-7H-pyrrolo[2,3-d]pyrimidin-4-amine (GSK2606414), a Potent and Selective First-in-Class Inhibitor of Protein Kinase R (PKR)-like Endoplasmic Reticulum Kinase (PERK). J. Med. Chem. 2012, 55, 7193-7207. [CrossRef]

23. Grubman, A.; Choo, X.Y.; Chew, G.; Ouyang, J.F.; Sun, G.; Croft, N.P.; Rossello, F.J; Simmons, R.; Buckberry, S.; Landin, D.V.; et al. Mouse and human microglial phenotypes in Alzheimer's disease are controlled by amyloid plaque phagocytosis through Hif1 $\alpha$. bioRxiv 2019, 639054 .

24. Bolger, A.M.; Lohse, M.; Usadel, B. Trimmomatic: A flexible trimmer for Illumina sequence data. Bioinformatics 2014, 30, 2114-2120. [CrossRef]

25. Dobin, A.; Davis, C.A.; Schlesinger, F.; Drenkow, J.; Zaleski, C.; Jha, S.; Batut, P.; Chaisson, M.; Gingeras, T.R. STAR: Ultrafast universal RNA-seq aligner. Bioinformatics 2013, 29, 15-21. [CrossRef]

26. Love, M.I.; Huber, W.; Anders, S. Moderated estimation of fold change and dispersion for RNA-seq data with DESeq2. Genome Biol. 2014, 15, 550. [CrossRef]

27. Eden, E.; Navon, R.; Steinfeld, I.; Lipson, D.; Yakhini, Z. GOrilla: A tool for discovery and visualization of enriched GO terms in ranked gene lists. BMC Bioinform. 2009, 10, 48. [CrossRef] [PubMed]

28. Huang, D.W.; Sherman, B.T.; Tan, Q.; Kir, J.; Liu, D.; Bryant, D.; Guo, Y.; Stephens, R.; Baseler, M.W.; Lane, H.C.; et al. DAVID Bioinformatics Resources: Expanded annotation database and novel algorithms to better extract biology from large gene lists. Nucleic Acids Res. 2007, 35, W169-W175. [CrossRef] [PubMed]

29. Cheng, G.; Zielonka, M.; Dranka, B.; Kumar, S.N.; Myers, C.R.; Bennett, B.; Garces, A.M.; Machado, L.G.D.D.; Thiebaut, D.; Ouari, O.; et al. Detection of mitochondria-generated reactive oxygen species in cells using multiple probes and methods: Potentials, pitfalls, and the future. J. Biol. Chem. 2018, 293, 10363-10380. [CrossRef]

30. Pakos-Zebrucka, K.; Koryga, I.; Mnich, K.; Ljujic, M.; Samali, A.; Gorman, A.M. The integrated stress response. EMBO Rep. 2016, 17, 1374-1395. [CrossRef]

31. Hetz, C.; Zhang, K.; Kaufman, R.J. Mechanisms, regulation and functions of the unfolded protein response. Nat. Rev. Mol. Cell Biol. 2020, 21, 421-438. [CrossRef]

32. Ristow, M.; Zarse, K. How increased oxidative stress promotes longevity and metabolic health: The concept of mitochondrial hormesis (mitohormesis). Exp. Gerontol. 2010, 45, 410-418. [CrossRef]

33. Peeva, V.; Blei, D.; Trombly, G.; Corsi, S.; Szukszto, M.J.; Rebelo-Guiomar, P.; Gammage, P.A.; Kudin, A.P.; Becker, C.; Altmüller, J.; et al. Linear mitochondrial DNA is rapidly degraded by components of the replication machinery. Nat. Commun. 2018, 9, 1-11. [CrossRef] [PubMed]

34. Valko, M.; Leibfritz, D.; Moncol, J.; Cronin, M.T.D.; Mazur, M.; Telser, J. Free radicals and antioxidants in normal physiological functions and human disease. Int. J. Biochem. Cell Biol. 2007, 39, 44-84. [CrossRef] [PubMed]

35. Hood, W.R.; Zhang, Y.; Mowry, A.V.; Hyatt, H.W.; Kavazis, A.N. Life History Trade-offs within the Context of Mitochondrial Hormesis. Integr. Comp. Biol. 2018, 58, 567-577. [CrossRef] [PubMed]

36. Da Silveira, W.A.; Fazelinia, H.; Rosenthal, S.B.; Laiakis, E.C.; Kim, M.S.; Meydan, C.; Kidane, Y.; Rathi, K.S.; Smith, S.M.; Stear, B.; et al. Comprehensive Multi-omics Analysis Reveals Mitochondrial Stress as a Central Biological Hub for Spaceflight Impact. Cell 2020, 183, 1185-1201.e20. [CrossRef] [PubMed]

37. Lei, X.G.; Zhu, J.-H.; Cheng, W.-H.; Bao, Y.; Ho, Y.-S.; Reddi, A.R.; Holmgren, A.; Arnér, E.S.J. Paradoxical Roles of Antioxidant Enzymes: Basic Mechanisms and Health Implications. Physiol. Rev. 2016, 96, 307-364. [CrossRef]

38. Marecki, J.C.; Parajuli, N.; Crow, J.P.; MacMillan-Crow, L.A. The Use of the Cre/loxP System to Study Oxidative Stress in Tissue-Specific Manganese Superoxide Dismutase Knockout Models. Antioxidants Redox Signal. 2014, 20, 1655-1670. [CrossRef] [PubMed]

39. Koopman, W.J.; Nijtmans, L.G.; Dieteren, C.E.; Roestenberg, P.; Valsecchi, F.; Smeitink, J.A.; Willems, P.H. Mammalian Mitochondrial Complex I: Biogenesis, Regulation, and Reactive Oxygen Species Generation. Antioxidants Redox Signal. 2010, 12, 1431-1470. [CrossRef] 
40. Boye, E.; Grallert, B. eIF2 $\alpha$ phosphorylation and the regulation of translation. Curr. Genet. 2019, 66, 293-297. [CrossRef]

41. Bazopoulou, D.; Knoefler, D.; Zheng, Y.; Ulrich, K.; Oleson, B.J.; Xie, L.; Kim, M.; Kaufmann, A.; Lee, Y.-T.; Dou, Y.; et al. Developmental ROS individualizes organismal stress resistance and lifespan. Nat. Cell Biol. 2019, 576, 301-305. [CrossRef] [PubMed]

42. Guillaumet-Adkins, A.; Yañez, Y.; Peris-Diaz, M.D.; Calabria, I.; Palanca-Ballester, C.; Sandoval, J. Epigenetics and Oxidative Stress in Aging. Oxidative Med. Cell. Longev. 2017, 2017, 1-8. [CrossRef] [PubMed] 